\title{
SPECTRAL KURTOSIS OF OTOACOUSTIC EMISSIONS USING THE HUSIMI TRANSFORM: A PILOT STUDY
}

\author{
Tomasz I. Siedlecki ${ }^{1}$, Jakub Zielinski ${ }^{1,2}$ \\ ${ }^{1}$ Department of Biophysics and Human Physiology, Warsaw Medical University, Warsaw, Poland \\ ${ }^{2}$ Interdisciplinary Centre for Mathematical and Computational Modelling, University of Warsaw, Warsaw, Poland \\ Corresponding author: Tomasz Siedlecki, Department of Biophysics and Human Physiology, Warsaw Medical \\ University, Chalubinskiego 5 Str., 02-004 Warsaw, Poland, e-mail: tsiedlecki@wum.edu.pl
}

\begin{abstract}
Background: Time-frequency distributions can help reveal resonant modes of OAEs. The Husimi transform is the time-frequency distribution of probability. The sound pressure probability density function for a given frequency can be derived from the Husimi transform. Using the Husimi transform as the weight function, it is possible to define the spectral kurtosis of OAEs.

Material and methods: The Husimi transform was calculated numerically from OAE data recorded from subjects with normal hearing. We examined click-evoked OAEs (CEOAEs) and tone-burst-evoked OAEs (TBOAEs) with stimuli centered at 1,2 , and $4 \mathrm{kHz}$, and the presence of spontaneous OAEs (SOAEs) was also investigated. The aim of this study was to examine the statistical properties of otoacoustic emissions (OAEs) and relate them to resonant modes of the cochlea. Assuming that the probability of the sound pressure of an OAE at any time and frequency is given by a Husimi-type transform, we analyzed statistical features of the probability distribution, particularly spectral kurtosis.
\end{abstract}

Results: With evoked OAEs, a minimum in kurtosis was found at frequencies close to SOAEs. With TBOAEs, three sorts of SOAEs were found: those with high positive kurtosis, those with small positive kurtosis, and those with negative kurtosis; in these cases, SOAEs appeared at the same frequency as the kurtosis minimum.

Conclusions: The kurtosis of evoked components of an OAE is strongly affected by the presence of an SOAE. The number of positive peaks and negative troughs of spectral kurtosis in a given frequency band seem to be characteristic of each subject. It is suggested that a new way of distinguishing types of OAEs may involve calculating the spectral kurtosis, and this may be diagnostically useful.

Key words: spontaneous otoacoustic emissions $\bullet$ probability $\bullet$ kurtosis $\bullet$ evoked otoacoustic emissions $\bullet$ statistical distributions $\bullet$ moments $\bullet$ stimulus frequency otoacoustic emissions

\section{CURTOSIS (ESPECTRAL) DE LA SEÑAL DE EMISIONES OTACÚSTICAS CON AYUDA DE LA TRANSFORMACIÓN DE HUSIMI - ESTUDIO}

\section{Resumen}

Antecedentes: Los planes de tiempo y frecuencia de la señal de emisiones otacústicas permiten reconocer modas de resonancia de la cóclea. La transformación de Husimi pertenece a esta clase funciones y describe el plan de probabilidad de la emisión en el tiempo y frecuencia. Al usar la función de Hisimi como función de peso podemos identificar y calcular la curtosis de la señal de emisiones otacústicas. La función de Husimi permite también leer la distribución de la densidad de probabilidad de tener un valor determinado de la presión acústica para una frecuencia de emisión determinada.

Material y métodos: Calculamos numéricamente la transformación de Husimi de los datos de la emisión otacústica registrados en pacientes con un oído normal. Se han estudiado emisiones otacústicas inducidas por un golpe EOAC o un tono de banda estrecha EOAT cuando la frecuencia media era de 1, 2 y $4 \mathrm{kHz}$. Analizamos también la presencia de otoemisiones acústicas espontáneas SOAE. El objetivo del estudio fue evaluar las propiedades de las otoemisiones estadísticas y su relación con las modas de resonancia de la cóclea. Suponiendo que la probabilidad de emisiones en cada momento y en cada frecuencia está determinada por la transformación de Husimi, analizamos las propiedades estadísticas de la distribución de la probabilidad y valores de la curtosis espectral de la señal de la emisión.

Resultados: Se observó que en caso de la señal de la otoemisión acústica inducida por un estímulo externo los valores mínimos de la curtosis correspondían a las frecuencias muy cercanas a las frecuencias espontáneas de la otoemisión acústica. Se afirmó que en caso de las otoemisiones acústicas inducidos por un tono, las emisiones espontaneas se pueden dividir en tres tipos según el valor de la curtosis obtenida en el punto mínimo: los de la curtosis negativa, de poca curtosis menor de 2 y los de un valor mayor de la curtosis. 
Resultados: La presencia de la otoemisión acústica espontanea afecta mucho a los valores de la curtosis de la señal de otoemisiones inducidas. De ahí, concluimos que el número de máximos y mínimos de la curtosis espectral en una banda de frecuencia dada es un rasgo característico de la persona examinanda. Esto sugiere que el cálculo de la curtosis de señales otoacusticas puede ser útil en la clasificación de diferentes tipos de emisiones y en el diagnóstico del oído interno.

Palabras clave: emisiones otoacústicas espontáneas • probabilidad de curtosis • emisiones otoacústicas inducidas • distribución estadística • momentos estadísticos • emisiones inducidas por una señal sinusoidal

\section{КУРТОЗИС (СПЕКТРАЛЬНЫЙ) СИГНАЛА ОТОАКУСТИЧЕСКОЙ ЭМИССИИ С ПОМОЩЬЮ ТРАНСФОРМАЦИИ ХУСИМИ - ПИЛОТАЖНОЕ ИССЛЕДОВАНИЕ}

\section{Изложение}

Фон: Временно-частотное распределение сигнала отоакустической эмиссии позволяет распознавать резонансные модули улитки. Трансформация Хусими принадлежит к функциям этого класса и описывает распределение правдоподобия эмиссии во времени и частотности. Используя функцию Хусими в качестве весовой функции можно определить и вычислить куртозис сигнала отоакустической эмиссии. Функция Хусими позволяет также считывать распределение густоты правдоподобия наличия определенного значения акустического давления для данной частоты эмиссии.

Материал и методы: Вычисляем цифровую трансформацию Хусими из данных отоакустической эмиссии, зарегистрированных у пациентов с нормальным слухом. Была исследована отоакустическая эмиссия, вызванная треском СЕОАЕ или узкополосным тоном ТВОАЕ, когда центральная частота была установлена на 1, 2 и 4 кГц. Мы анализировали также наличие спонтанной акустической отоэмиссии SOAE. Целью исследования являлась оценка статистических свойств отоэмиссии, а также их связь с акустическими модулями улитки. Предполагая, что правдоподобие эмиссии в каждый момент и на каждой частоте определяется трансформацией Хусими, мы анализировали статистические свойства распределения правдоподобия и значение спектрального куртозиса сигнала эмисии.

Результаты: Замечено, что в случае сигнала акустической отоэмисии, вызванной внешней стимуляцией, минимальные значения куртозиса соответствовали частотам, очень подобным частотам спонтанной акустической отоэмиссии. Обнаружено, что в случае акустической отоэмиссии, вызванной тоном, спонтанную отоэмиссию можно разделить на три вида, в зависимости от значения куртозиса, достигнутого в пункте минимум: отоэмиссия с отрицательным куртозисом, отоэмиссия с небольшим куртозисом - меньше 2 и отоэмиссия с высшим значением куртозиса.

Итоги: Наличие спонтанной акустической отоэмиссии имеет большое влияние на значение куртозиса сигнала вызванной отоэмиссии. Ввиду этого мы приходим к выводу, что количество максимумов и минимумов спектрального куртозиса в данной полосе частот является характеристическим свойством исследованного человека. Это наводит на мысль, что вычисление куртозиса сигнала отоакустической эмиссии может быть полезно в классификации разных видов эмиссии, а также в диагностике внутреннего уха.

Ключевые слова: акустическая спонтанная отоэмиссия • правдоподобие • куртозис • акустическая вызванная отоэмиссия - статистическое распределение - статистические моменты • эмиссия • вызванная синусоидальным сигналом

\section{KURTOZA (SPEKTRALNA) SYGNAŁU EMISJI OTOAKUSTYCZNYCH Z POMOCA TRANSFORMACJI HUSIMI'EGO - BADANIE PILOTAŻOWE}

\section{Streszczenie}

Tło: Rozkłady czasowo-częstotliwościowe sygnału emisji otoakustycznej pozwalają rozpoznać mody rezonansowe ślimaka. Transformacja Husimiego należy do tej klasy funkcji i opisuje rozkład prawdopodobieństwa emisji w czasie i częstotliwości. Używając funkcji Husimiego jako funkcji wagowych możemy zdefiniować i obliczać kurtozę sygnału emisji otoakustycznych. Funkcja Husimiego pozwala również odczytać rozkład gęstości prawdopodobieństwa posiadania określonej wartości ciśnienia akustycznego dla danej częstotliwości emisji.

Materiał i metody: Obliczamy numerycznie transformację Husimi'ego z danych emisji otoakustycznej zarejestrowanych u pacjentów z normalnym słuchem. Badano emisje otoakustyczne wywołane trzaskiem CEOAE lub tonem wąskopasmowym TBOAE kiedy częstotliwość środkowa była umiejscowiona na 1,2, i 4 kHz. Analizowaliśmy także obecność spontanicznych 
otoemisji akustycznych SOAE. Celem badania była ocena właściwości statystycznych otoemisji oraz ich związek z modami akustycznymi ślimaka. Przypuszczając, że prawdopodobieństwo emisji w każdym momencie i na każdej częstotliwości jest określane przez transformację Husimi’ego, analizowaliśmy cechy statystyczne rozkładu prawdopodobieństwa i wartość kurtozy widmowej sygnału emisji.

Wyniki: Zaobserwowano, że w przypadku sygnału otoemsji akustycznej wywołanej zewnętrznym pobudzeniem minimalne wartości kurtozy odpowiadały częstotliwościom bardzo bliskim częstotliwości spontanicznych otoemisji akustycznych. Stwierdzono, że przypadku otoemisji akustycznych wywołanych tonem, emisje spontaniczne można podzielić na trzy rodzaje w zależności od wartości kurtozy osiągniętej w punkcie minimum: te o ujemnej kurtozie, o niewielkiej kurtozie mniejszej niż 2 oraz te o wyższej wartości kurtozy.

Wnioski: Obecność spontanicznej otoemisiji akustycznej bardzo wpływa na wartość kurtozy sygnału otoemisji wywołanej. Wnioskujemy stąd, że liczba maksimów i minimów kurtozy widmowej w danym paśmie częstotliwości jest charakterystyczną cechą badanej osoby. Sugeruje to, że obliczanie kurtozy sygnału emisji otoakustycznych może być pomocne w klasyfikowaniu różnych typów emisji i użyteczne w diagnostyce ucha wewnętrznego.

Słowa kluczowe: otoemisja akustyczna spontaniczna • prawdopodobieństwo • kurtoza • otoemisje akustyczne wywołane • rozkład statystyczny $\bullet$ momenty statystyczne $\bullet$ emisje wywołane sygnałem sinusoidalnym

\section{Background}

In standard otoacoustic emission (OAE) measurements, the signal is recorded as the average of many responses to a stimulus [1]. Looking at the averaged response it is easy to forget that further statistical content is available. The probability distribution function of an emission signal and its statistical moments may help us better understand the mechanisms of hearing in humans.

One method used to analyze OAEs is to investigate the time-frequency (TF) distribution of their energy [2]. The TF distribution can be calculated by decomposing the signal into simple components called resonant modes and identifying their energy or amplitude. In this way, the TF distributions of energy can reveal the resonant modes of the cochlea and show their latencies. It is known that the cochlea has three kinds of resonant modes: very short duration and wide bandwidth modes evoked by an external signal; longer-lasting narrowband modes exponentially decaying with time; and stable sustained long-lasting narrowband modes, related to spontaneous OAEs (SOAEs) [3]. The decaying modes often exhibit temporal asymmetry because, for a given frequency, they have different rise and fall times [4]. To see the cochlea's resonant modes we need to apply mathematical methods of TF signal analysis to OAEs. There are many different TF methods, among the most popular being the wavelet transform [5], Wigner-Ville methods [6,7], and the matching pursuit algorithm [8]. It is claimed that the matching pursuit method gives the best combination of time and frequency resolution on TF distributions of energy [8].

Keefe [9] used TF distributions of the Cohen class as weight functions to calculate temporal and spectral moments of click-evoked OAEs (CEOAEs). The group delay (GD) and the group spread represent temporal moments, whereas the instantaneous frequency (IF) and instantaneous bandwidth (IB) represent spectral moments of CEOAEs. Keefe found GD and IF significantly reduced in ears with hearing impairments [9]. Furthermore, he found that moments are strongly influenced by the presence of synchronized spontaneous otoacoustic emissions (SSOAEs) which are considered to describe SOAEs [10].
There are two theories of generation of SOAEs. The first theory originated from Gold's prediction [11] that local elements of the organ of Corti may become self-oscillatory when damping in the fluid is strongly counteracted by nonlinear active feedback forces. Nonlinear oscillators at one cochlear site become synchronized and begin to oscillate spontaneously. It means their local frequencies at one site becomes similar and correspond to the frequency of SOAEs detected in the outer ear canal [12]. According to a second theory [13], SOAEs are a global property of the cochlea because they are amplitude stabilized standing waves produced by a hydromechanical cochlear laser $[13,14]$ in which travelling waves are locally amplified and partially reflected between the stapes and the peak of the waves. In the first theory it is easier to link the frequency of an SOAE with a local cochlear site and thereby explain the temporal dynamics of TEOAE responses at SOAE frequencies for different stimulus levels $[15,16]$. The evoked oscillator response at an SOAE frequency is strongly deterministic, and should decay quickly for higher stimulus levels and be more stationary for lower stimulus levels $[15,16]$. Our pilot study is based on a small data sample; however it tends to indicate differences in the value of OAE kurtosis, a quantity which depends on the statistical moments of OAEs.

The present study investigates application of the Husimi transform to OAE analysis. The Husimi transform has been used in quantum physics [17] where it has a simple interpretation as the quasi probability of the coherent state. The Husimi transform belongs to smoothed Wigner-Ville methods of signal analysis (see the Appendix) which are known to produce plots with poorer resolution in the TF distribution of energy. In acoustics, the Husimi function describes the probability of having at instant $t$ an emission signal with frequency $f$. This means that the Husimi time-frequency distribution function may be used as a weight function to calculate the moments of CEOAEs and the kurtosis of OAEs. We wanted to investigate whether the kurtosis can be affected by SOAEs, since it is known that statistical moments are influenced by the presence of SSOAEs [9].

Statistical properties of OAEs have been the subject of many articles $[18,19]$. Using a sensitive microphone and 
6 minutes of continuous recording, Bialek [18] derived ear canal sound pressure probability distribution functions (PDFs) from a subject who had a prominent SOAE at a frequency of $1415 \mathrm{~Hz}$. It turned out that in the frequency band close to the emitted frequency the distribution function was bimodal, and quite different from the Gaussian distributions found in frequency bands far from the emitted frequency.

Kurtosis is a statistical measure of the shape of a probability distribution function. For random signals, kurtosis is equal to 0 for a random Gaussian signal or to -1.5 for a sinusoidal signal. The Husimi TF distribution is not an explicit function of sound pressure. However the value of the Husimi TF function does depend on the shape of the stochastic complex envelope of the OAE signal. The frequency integral of a TF distribution is equal to the square of the sound pressure at any given time [9]. Therefore temporal histograms of a Husimi function at a given frequency should also yield the sound pressure PDF (as in the work of Bialek [18]). Spectral kurtosis may depend on the selected frequency band because the PDF in one band can differ from the PDF in a second band. Hence kurtosis can tell us about the PDFs of OAEs.

The purpose of this study was to examine resonance modes of cochlea and the associated statistical properties of OAEs. Of special interest was the kurtosis of OAEs, and its relation to evoked and spontaneous resonance modes.

\section{Material and methods}

\section{Material}

OAEs were recorded from both ears of seven normally hearing subjects ( 5 females, 2 males, age 28-37 years) using the ILO96 system (Otodynamics Ltd., Hatfield, U.K.). All subjects had no otoscopic ear abnormalities, and hearing thresholds were better than $20 \mathrm{~dB}$ HL. Click-evoked OAEs (CEOAEs) and tone-burst-evoked OAEs (TBOAEs) with stimuli centered at 1,2 , and $4 \mathrm{kHz}$ were measured. Stimuli were presented at $80 \mathrm{~dB}$ pSPL and a nonlinear averaging protocol was used. Signals were recorded in a $20 \mathrm{~ms}$ window. The initial part of the signal was filtered in order to remove stimulus artifacts. All subjects were additionally tested for the presence of synchronized spontaneous OAEs (SSOAEs) using the technique provided by the ILO96 equipment. SOAEs in the frequency band $1-3.5 \mathrm{kHz}$ were clearly detected in subjects $2,3,5,6$, and 7. SOAEs in the higher frequency band $4-5 \mathrm{kHz}$ were detected in subject 1 and for the right ear of subject 4 . However SOAEs were not detected in the left ear of subject 4 .

\section{Methods}

The term spectral kurtosis has been applied to analysis of time series data [20]. Using the short-time Fourier transform, Antoni [20] defined $S_{2 n Y}(f)$, the $2 n$-th order spectral moment of the Fourier-transformed amplitude $Y(f)$, and the spectral kurtosis $K(f)$ as the ratio [21]:

$$
K(f)=\frac{\mathrm{S}_{4 \mathrm{Y}}(f)}{\left(S_{2 \mathrm{Y}}(f)\right)^{2}}-2 .
$$

Here the latency of the signal is not important. Furthermore the mean value of the amplitude of the signal has been assumed to be zero. In our calculations we chose the Gaussian function as the window function to calculate the spectral kurtosis according to Antoni.

The Husimi function of the otoacoustic signal $H(t, \omega)$ used here as the measure of probability is defined as follows [21] (see Appendix):

$$
H(t, f)=\frac{1}{2 \pi} \sqrt{\frac{\kappa}{\pi}}\left|\int_{-\infty}^{+\infty} e^{-\kappa(\tau-t)^{2} / 2} e^{-2 \pi \imath f \tau} Y(\tau) d \tau\right|^{2} .
$$

The Husimi function has been used in optics [21] and quantum mechanics to estimate the probability of the coherent state. Our Husimi function represents the probability distribution function on the time-frequency plane. It is the probability of having a signal of frequency $f$ at a particular time $t$. Thus $H(t, f)$ is the probability distribution function.

We can define the conditional probability $P(t \mid f)$ of having the emission signal at time $t$ when we know that its IF is $f$ :

$$
P(t \mid f)=\frac{H(t, f)}{\sum_{l=1}^{n} H\left(t_{l}, f\right)},
$$

where the sum in the denominator is the probability of having the IF of the signal equal to $f$. Similarly we can define $P(f \mid t)$ as the probability of having an emission at a specific frequency $f$ when we know the emission time $t$.

Summing over time, we can define the spectral kurtosis of the otoacoustic signal as:

$$
K(f)=-3+\frac{\sum_{l=1}^{n} P\left(t_{l} \mid f\right)\left(t_{l}-T_{m}\right)^{4}}{\left(\sum_{l=1}^{n} P\left(t_{l} \mid f\right)\left(t_{l}-T_{m}\right)^{2}\right)^{2}},
$$

where $T_{m}(f)$ is the mean latency or group delay (GD) for frequency $f$.

The mean emission delay $T_{m}$ or mean latency can be defined as:

$$
T_{m}(f)=\sum_{i=1}^{n} t_{i} \cdot P\left\langle t_{i} \mid f\right\rangle,
$$

and it can take a different value from the simple latency defined as the time to the maximum of the probability function. For the temporal kurtosis $K(t)$ we use $P(f \mid t)$ and sum it over frequency if the mean frequency is given by the IF.

\section{Simple Husimi functions}

Consider the case where the emission signal is described by a sinusoid with symmetric Gaussian function envelope given by the equation:

$$
Y(t)=e^{\frac{-(x-7)^{2}}{2 \sigma^{2}}} \sin (2 \pi f t+\phi)
$$

where $\sigma$ is the width of the envelope, $\varphi$ the additional phase, and $t$ is time. Figure 1 presents the example of a signal with frequency $2 \mathrm{kHz}$ in a time window of $20 \mathrm{~ms}$. The maximum occurs at $7 \mathrm{~ms}$, and the time width of the signal is $0.44 \mathrm{~ms}$.

The Husimi function of the signal from Figure 1 is shown in Figure 2. The function is localized in the time and the 


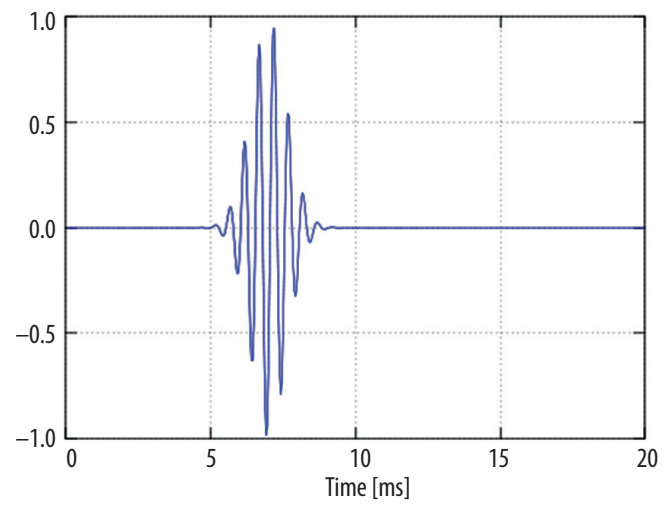

Figure 1. A sinusoid with Gaussian envelope. The midfrequency of the signal is $2 \mathrm{kHz}$

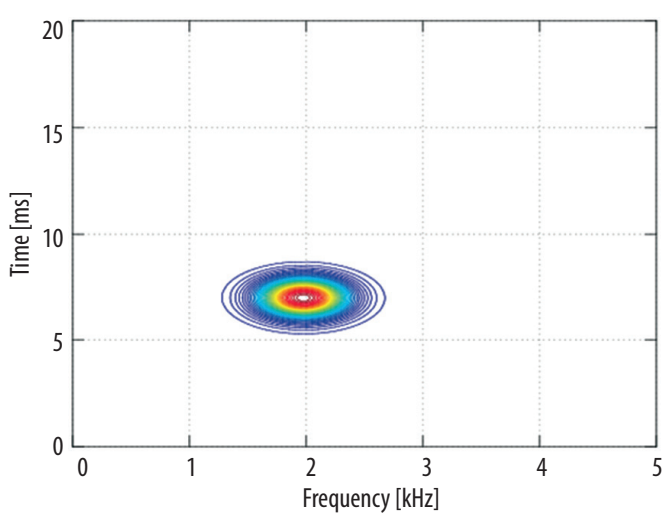

Figure 2. The Husimi function of the sinusoid with Gaussian envelope from Figure 1, with $\sigma \mathrm{t}=0.44 \mathrm{~ms}$. The latency is $7 \mathrm{~ms}$

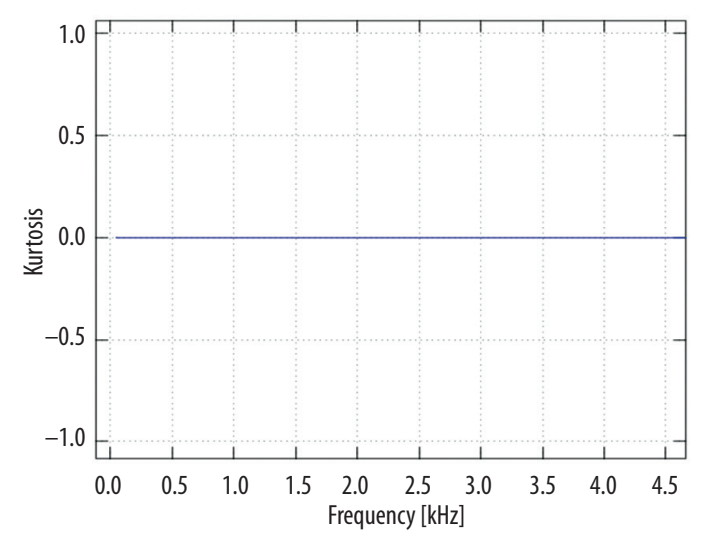

Figure 3. The spectral kurtosis of the signal with Gaussian envelope from Figure 1 as a function of frequency

frequency domains. The spectral width is about $200 \mathrm{~Hz}$. The spectral kurtosis of the signal with Gaussian envelope can be readily calculated.

Because the spectrum of the signal with Gaussian envelope is also Gaussian, we therefore expect that the kurtosis of

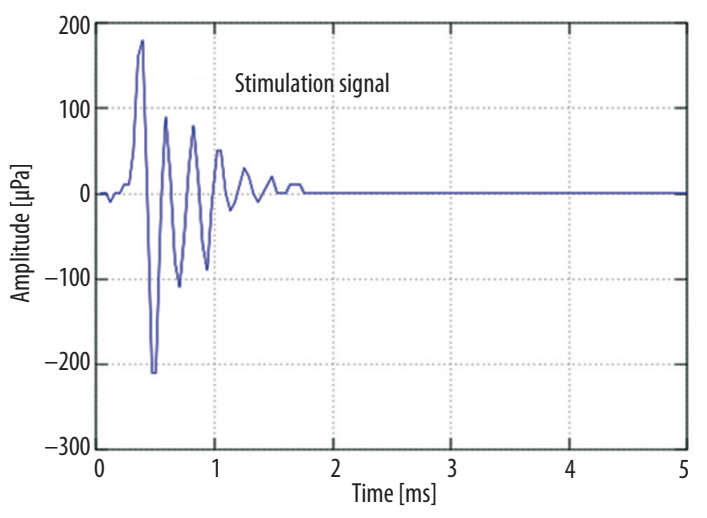

Figure 4. The time evolution of the stimulus signal. The mid-frequency is $4 \mathrm{kHz}$

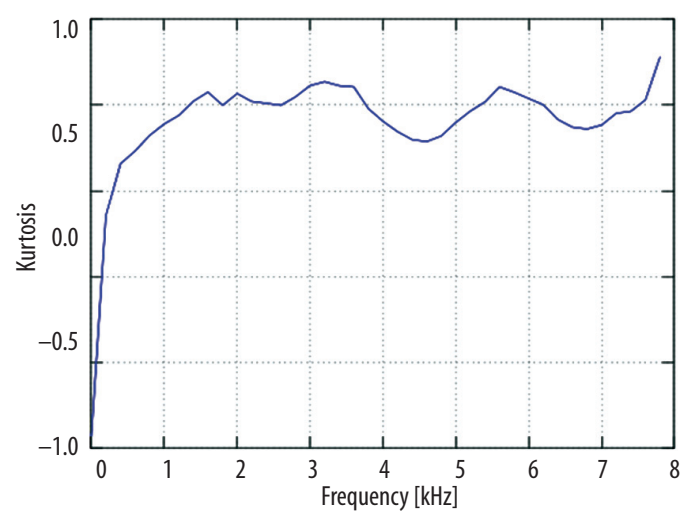

Figure 5. Spectral kurtosis of the stimulation signal, with $\sigma \mathrm{t}=1.77 \mathrm{~ms}$

the signal is zero. We know that the spectrum of the signal contains frequencies between 1.5 and $2.5 \mathrm{kHz}$. Figure 3 shows the spectral kurtosis of the signal with Gaussian envelope as a function of frequency.

An example of the actual stimulation signal used in our experiment is depicted in Figure 4. The signal differs from a Gaussian shape and its kurtosis is not equal to zero. The spectral kurtosis of the stimulation signal is more complicated and is shown in Figure 5. Although the value of the kurtosis is close to zero, it is not constant.

The statistical properties of the stimulation signal can be compared with the statistical properties of the emitted signal.

\section{Results}

We found that the OAE signals from the seven healthy subjects showed a significant degree of diversity in the way they evolved over time. The diversity is also seen in the kurtosis plots. In the following, we present the Husimi probability distributions, the mean latencies, and the spectral kurtosis of emissions as a function of emitted frequency. 


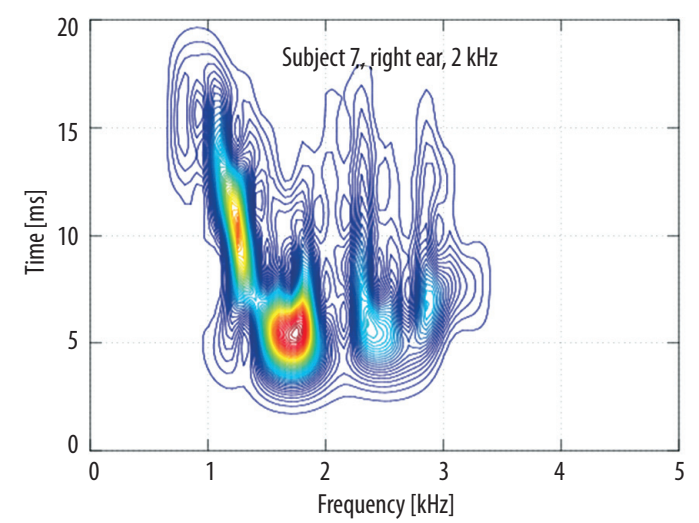

Figure 6. The Husimi distribution for subject 7, right ear, TBOAE (2 kHz), $\sigma \mathrm{t}=1.77 \mathrm{~ms}$

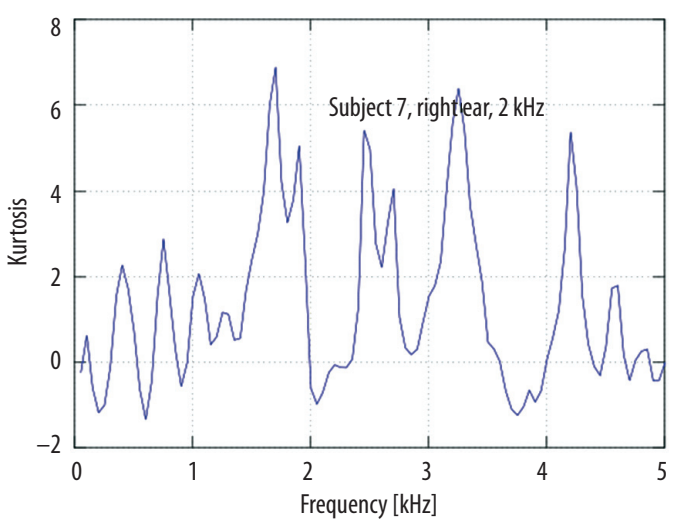

Figure 7. Spectral kurtosis of subject 7 calculated from the $2 \mathrm{kHz}$ TBOAE, $\sigma \mathrm{t}=1.77 \mathrm{~ms}$. The kurtosis has 7 minima in the frequency band between 1 and $3 \mathrm{kHz}$ (at 1150 , 1350, 1800, 2050, 2300, 2600, and $2850 \mathrm{~Hz}$ ). In comparison, the kurtosis of the stimulus signal remains close to zero throughout $1-3 \mathrm{kHz}$

The Husimi distribution and the corresponding spectral kurtosis of a subject with many SOAEs are shown in Figures 6 and 7. Figure 6 presents the Husimi distribution for a $2 \mathrm{kHz}$ TBOAE of the right ear of subject 7, which is known to emit spontaneously, and Figure 7 shows the spectral kurtosis of the same signal. Looking for kurtosis minima, there are seven in the frequency band up to $3 \mathrm{kHz}$.

Frequencies above $3.5 \mathrm{kHz}$ can be ignored because the mid-frequency of stimulation was $2 \mathrm{kHz}$ and so noise may lead to incorrect kurtosis values. When the kurtosis calculations are repeated using the formula given by Antoni [20], the result is seen in Figure 8. The shape of the plot is similar to before; however the kurtosis values differ somewhat from the values calculated from the Husimi transform.

In Figure 8 there are now eight kurtosis minima in the band $1-3 \mathrm{kHz}$, with at least one new minimum at 1550 $\mathrm{Hz}$. Furthermore, the minimum at $2300 \mathrm{~Hz}$ is much deeper than in Figure 7. An SOAE at $2300 \mathrm{~Hz}$ can be seen in the Husimi distribution of Figure 6, but there is no clear

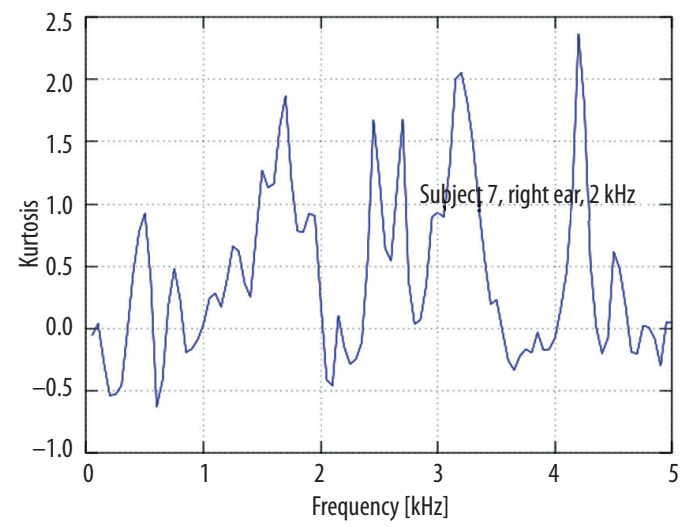

Figure 8. Spectral kurtosis of subject 7 calculated from the $2 \mathrm{kHz}$ TBOAE using the Antoni formulas and $\sigma \mathrm{t}=1.77$ ms. Kurtosis minima occur at 1150, 1350, 1550, 1800, 2050, 2300, 2600, and $2850 \mathrm{~Hz}$, frequencies which correspond to SOAES

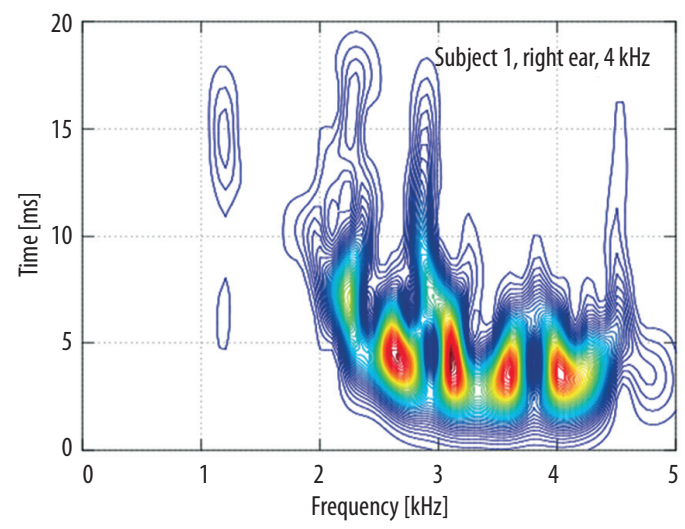

Figure 9. Husimi probability distribution for the right ear of subject 1 , with TBOAE stimulation at $4 \mathrm{kHz}$ and $\sigma \mathrm{t}=1.77 \mathrm{~ms}$. Four strong resonant modes are clearly seen at $2700,3100,3600$, and $4100 \mathrm{~Hz}$

emission at $2050 \mathrm{~Hz}$. Figure 7 shows that the kurtosis at $2050 \mathrm{~Hz}$ is negative.

Turning now to another subject, subject 1, the resonant modes in the right ear for a $4 \mathrm{kHz}$ TBOAE can be seen in the Husimi distribution of Figure 9. The mean latencies of the signal from the same ear are shown in Figure 10. However our mean latencies represent the probability densityweighted emission time and are not directly comparable with the latencies measured by other authors $[4,22]$. Two distinctive maxima can be seen in Figure 10.

The first one at $4550 \mathrm{~Hz}$ has a mean latency about $8 \mathrm{~ms}$ (some $3 \mathrm{~ms}$ longer than other studies [4]) and the second maximum at $2910 \mathrm{~Hz}$ also has a latency of about 8 ms (about 2 ms longer than typical). The peak at $2900 \mathrm{~Hz}$ does not correspond with an SOAE, although it does have a negative kurtosis value in Figure 11. The peak may be a numerical artifact or perhaps a stimulus frequency otoacoustic emission (SFOAE) [23] which may have a frequency equal to one of the frequencies in the stimulus. 


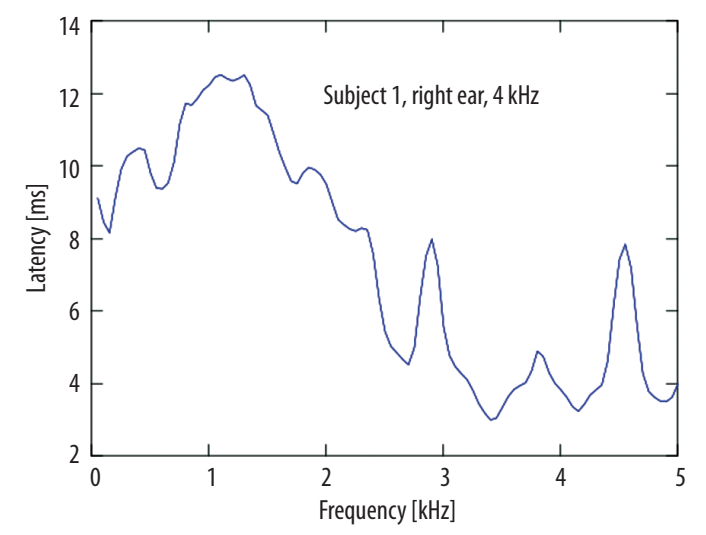

Figure 10. Latencies for the $4 \mathrm{kHz}$ TBOAE ( $\sigma \mathrm{t}=1.77 \mathrm{~ms}$ ) from the right ear of subject 1 . Strong peaks at 2900 and $4550 \mathrm{~Hz}$ can be seen

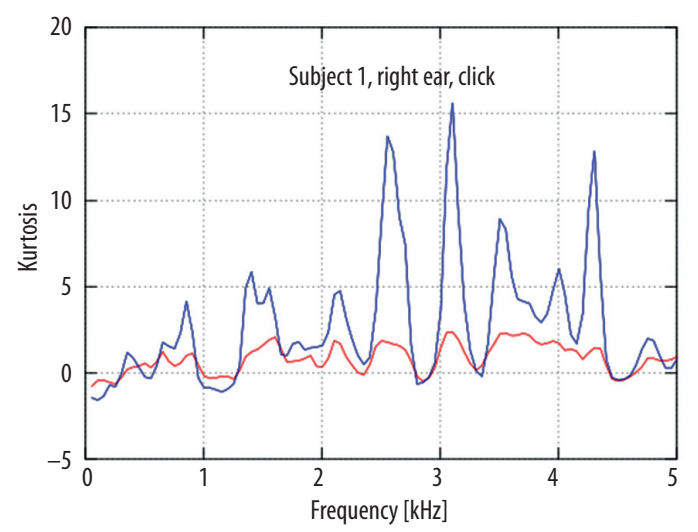

Figure 11. Spectral kurtosis for subject 1, right ear, CEOAE, $\sigma \mathrm{t}=1.77 \mathrm{~ms}$. The red line represents calculations according to formulae given by Antoni [14] and the blue line represents kurtosis calculated from the conditional probability of the Husimi transform

However, the kurtosis minima at 4480,1200 , and $2300 \mathrm{~Hz}$ do represent SOAEs. In Figure 11 we compare the kurtosis calculated according to formulae by Antoni [20] with the kurtosis calculated from the conditional probability of the Husimi transform.

However, the problem of reproducibility calls for closer examination. How certain is it that an estimated kurtosis value is fixed for a given individual? To answer the question we need to compare Husimi distributions and the kurtosis calculated from the CEOAE data with the kurtosis calculated with TBOAE data from the same subject. Subject 2 has a very strong emission line at $1950 \mathrm{~Hz}$, which can be seen in the CEOAE Husimi distribution shown in Figure 12. Looking for kurtosis minima, we find them at frequencies of 1080, 1300, 1980, 2400, and $3300 \mathrm{~Hz}$. These frequencies correspond to SOAEs. When the Husimi transform is calculated from $4 \mathrm{kHz}$ TBOAE data as shown in Figure 13, the emission line at $1950 \mathrm{~Hz}$ is stronger and its decay time much longer than in the case of CEOAE. This result is consistent with the dynamical model of Sisto et al. [15] because when using a TBOAE of $4 \mathrm{kHz}$, the

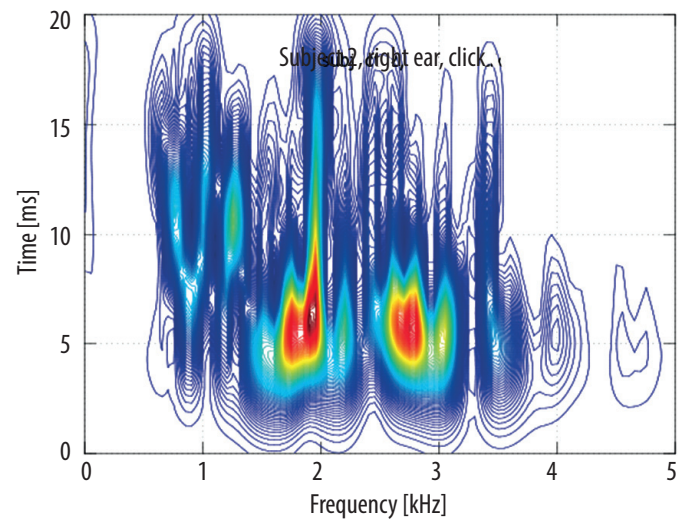

Figure 12. The Husimi distribution for subject 2, left ear, CEOAE, $\sigma \mathrm{t}=2.47 \mathrm{~ms}$. An SOAE at $1950 \mathrm{~Hz}$ is clearly visible

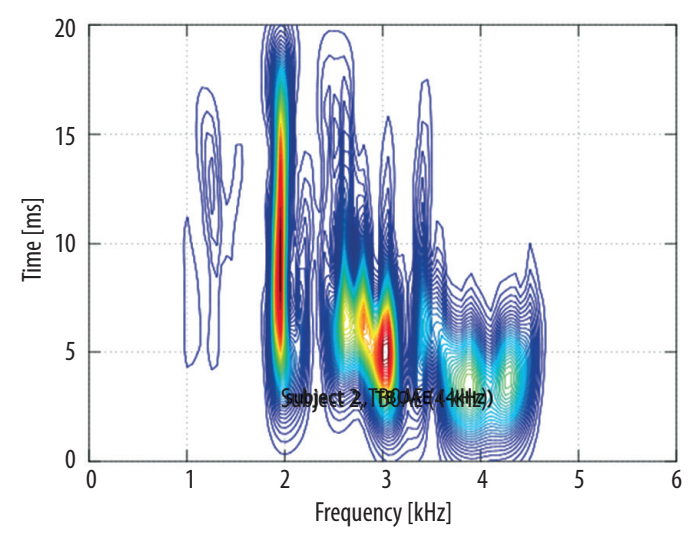

Figure 13. The Husimi distribution for subject 2, left ear, TBOAE, $4 \mathrm{kHz}, \sigma \mathrm{t}=2.47 \mathrm{~ms}$. A stationary line at $1950 \mathrm{~Hz}$ is seen

stimulus has low spectral energy at the SOAE frequency. Hence more stationary line response with a longer decay time can be seen in Figure 13.

Histograms of the square root of the Husimi transform, which is equal to the PDF of the sound pressure, are shown in Figure 14 for four different frequencies.

The reproducibility of the kurtosis can be estimated as the correlation coefficient between kurtosis from CEOAE data and from $2 \mathrm{kHz}$ TBOAE data (Figure 15). A correlation coefficient of 0.55 suggests a low degree of similarity when different stimulation signals are used. A parameter for the assessment of otoacoustic emissions should not depend on factors other than the emission. Unfortunately the kurtosis of otoacoustic signals depends partly on the stimulation signal. This suggests that the kurtosis of the stimulus signal is one factor which contributes to reproducibility.

Results from all seven subjects are listed in Table 1. Figure 16 shows a comparison between the frequencies of SOAE spectral peaks and the frequencies at which the kurtosis has a minimum. There seems to be a good match between the frequencies. The last column of Table 1 gives frequencies corresponding to minima of kurtosis, and 

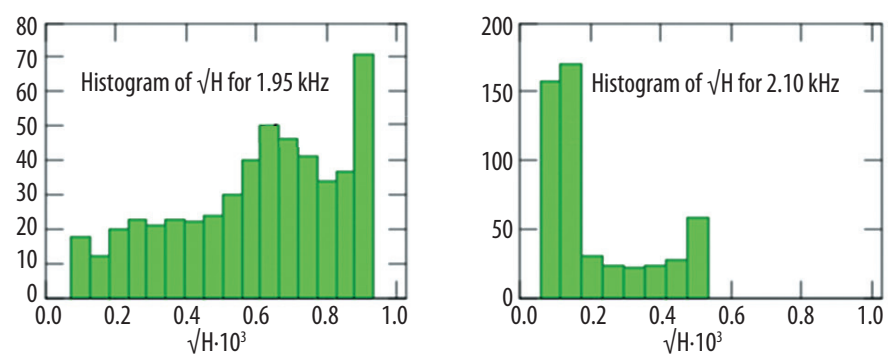

Figure 14. PDFs of sound pressure for four different frequencies shown as histograms of the Husimi transform of CEOAE data from subject 2. Plot at top left is for $1.95 \mathrm{kHz}$, a frequency where the kurtosis is negative and which corresponds to the SOAE appearing as the peak in Figure 12. The other three PDFs, chosen at frequencies away from the SOAE, have different profiles
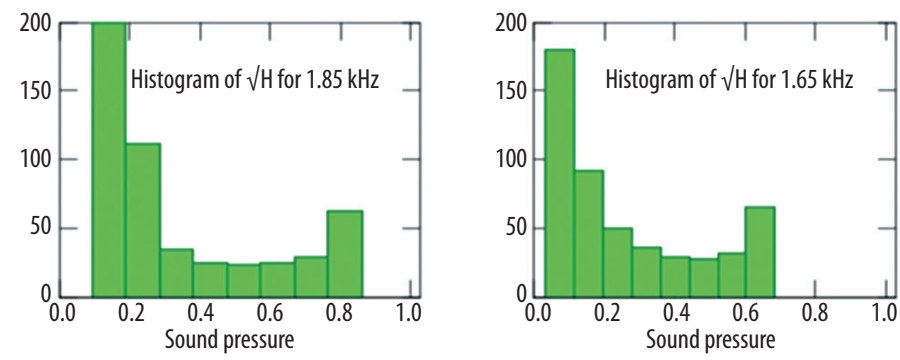

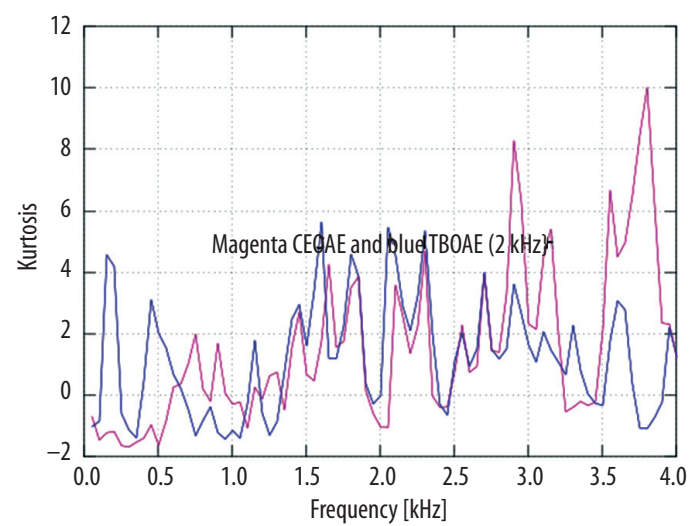

Figure 15. Kurtosis for subject 2 calculated for CEOAE (magenta) and $2 \mathrm{kHz}$ TBOAE (blue). The correlation coefficient is 0.55 for the band between 1 and $3 \mathrm{kHz}$. $\sigma \mathrm{t}=2.47 \mathrm{~ms}$

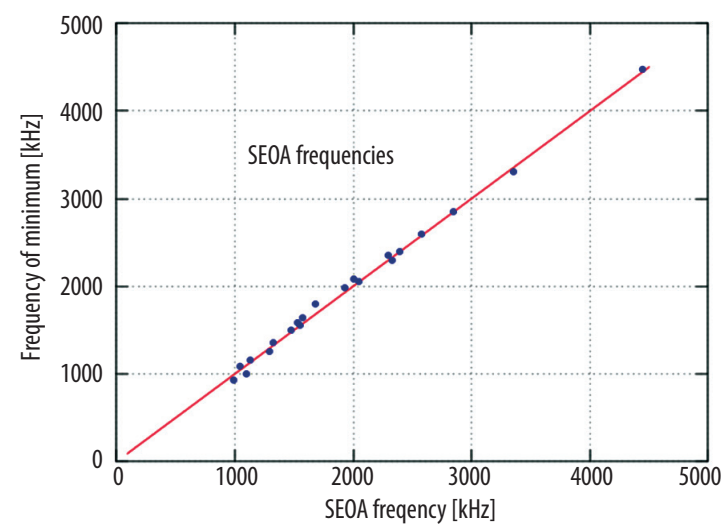

Figure 16. Frequencies at which the value of kurtosis has a minimum plotted against measured frequencies of SOAES.

Table 1. Comparison of SOAE frequencies and kurtosis frequencies

\begin{tabular}{cll}
\hline & \multicolumn{1}{c}{$\begin{array}{c}\text { Measured frequencies of SOAEs } \\
\text { (spectral peaks) }\end{array}$} & \multicolumn{1}{c}{$\begin{array}{c}\text { Frequencies of kurtosis minima } \\
\text { (when kurtosis K } \leq \text { 2) }\end{array}$} \\
\hline Subject 1, right ear & $1294,2295,4443 \mathrm{~Hz}$ & $1250,2350,2850,3320,4480 \mathrm{~Hz}(\mathrm{CEOAE})$ \\
\hline Subject 2, left ear & $867,1038,1929,2393,2580,3357 \mathrm{~Hz}$ & $\begin{array}{l}1080,1300,1500,1980,2400,2600,3300 \mathrm{~Hz} \\
(\mathrm{CEOAE})\end{array}$ \\
\hline Subject 3, left ear & $1526 \mathrm{~Hz}$ & $1310,1590,2010 \mathrm{~Hz}(\mathrm{CEOAE})$ \\
\hline Subject 4, right ear & $4443 \mathrm{~Hz}$ & $1100,1450,4550 \mathrm{~Hz}(\mathrm{CEOAE})$ \\
\hline Subject 5, right ear & $989,1123,1575,2002 \mathrm{~Hz}$ & $810,930,1140,1640,2090 \mathrm{~Hz}(\mathrm{CEOAE})$ \\
\hline Subject 6, right ear & $1100,1200,1475,2050 \mathrm{~Hz}$ & $1000,1500,2050 \mathrm{~Hz}(\mathrm{TBOAE})$ \\
\hline Subject 7, right ear & $1125,1325,1550,1675,2050,2325,2575$, & $\begin{array}{l}1150,1350,1550,1800,2050,2300,2600, \\
2850 \mathrm{~Hz}(\mathrm{TBOAE}, 2 \mathrm{kHz})\end{array}$ \\
\hline
\end{tabular}


it can be seen that frequencies occur which do not correspond with those of true SOAEs. For subject 1, three of the five frequencies found from calculating kurtosis correspond with SOAEs. However for subject 7, all eight SOAE frequencies correspond with minima of kurtosis of the TBOAE signal. For subject 6, two SOAE frequencies do not have an equivalent kurtosis minimum. However, for subject 2 who had six SOAEs, the kurtosis of the CEOAE data showed seven minima, five of which corresponded with SOAEs. The two additional unknown frequencies may represent numerical artifacts, SSOAEs, or stimulus frequency otoacoustic emissions (SFOAEs) [23].

\section{Discussion}

The work of Bialek [18] has shown the relevance of OAE sound pressure probability distributions in otolaryngology. Kurtosis can be determined from the sound pressure probability density function (PDF), and the profile of the PDF can be read off from the Husimi time-frequency distribution.

The larger the value of the time constant $\sigma t$ chosen in the Husimi transform, the better is the frequency resolution. A suitable choice of the constant is needed to discriminate two tones that produce beating in the OAE response. To distinguish two lines in the SOAE spectrum $500 \mathrm{~Hz}$ apart requires a time constant greater than $2 \mathrm{~ms}$. This value is still insufficient for neonates where the emission lines are closer together.

The statistical moments of energy distributions of CEOAEs have been examined by Keefe [9]. Keefe used the group spread as the measure of temporal dispersion of CEOAE, which is defined as the second-order temporal moment of CEOAE. Keefe found that the moments were strongly influenced by the presence of SSOAEs [9]. The value of kurtosis is calculated from the group spread because our kurtosis depends on the temporal dispersion of a CEOAE. Of course the kurtosis is also proportional to the fourthorder temporal moment, and the final result may be uncertain. Since statistical moments are affected by SSOAEs, we wanted to find out whether SOAEs can also affect kurtosis. Our results confirm that SOAEs can in fact have a profound effect on the value of kurtosis of evoked OAEs in the frequency band close to the frequency of the SOAE.

Kurtosis is the measure of the shape of the probability density function and takes on values different from zero when the function deviates from the Gaussian. For example, the probability density function found by Bialek [18] is similar to the binomial probability distribution and should have negative kurtosis. A Gaussian distribution has a kurtosis equal to 0 , and the kurtosis of a sinusoidal function is equal to -1.5 . Does this mean that the kurtosis of an SOAE should always be negative? Figures 7 and 8 show the spectral kurtosis for the right ear of the subject 7 . In the frequency range $1-3.5 \mathrm{kHz}$, we found eight minima which correspond to SOAEs. However, only two of them have negative kurtosis, suggesting that the kurtosis of an SOAE might be small but does not have to be negative. The suggestion is made that SOAEs may be classified according to the value of the corresponding kurtosis. While the emission detected by Bialek had negative kurtosis, less negative values of kurtosis might also indicate a high probability of an SOAE emerging from an active process which might produce an SOAE.

We were not able to find estimations of kurtosis for OAEs in other publications. Therefore we compared two methods of calculations of kurtosis. The first was proposed by Antoni [20], a method which allows faults in bearings to be diagnosed based on the sound they emit. The second method proposed in this article is based on the Husimi probability distribution and takes into account the mean latency of an emission. The first method calculates the true spectral kurtosis because it uses Fourier-transformed amplitude. The second method uses the frequency-dependent Husimi probability density as the weight function, and the temporal dependence of the OAE signal to obtain the spectral kurtosis with hidden time dependence. Looking at Figure 11, we see that the maximum values of kurtosis calculated according to Antoni's equations [20] are much smaller than the values of kurtosis calculated from Husimi functions. However, the minimum values of kurtosis are similar in the two methods, and the frequencies of the minima are identical in both cases (Figure 11). This means that the two methods can lead to the same result if we want to analyse the kurtosis of SOAEs.

\section{Conclusions}

It may be possible to use spectral kurtosis to classify the type of otoacoustic emission. A decrease in kurtosis, or a small or negative value, may confirm the presence of an SOAE. However there are additional frequencies at which kurtosis has a minimum but there are no SOAEs. The Husimi probability distribution allows us to see extended activity in the same frequency band as corresponds to an SOAE emission. The mean latency in the frequency band of an SOAE should be longer than the normal latency.

Spectral kurtosis can help detect the presence of additional noise in a background of global kurtosis. However it also makes it possible to detect the presence of coherent signals (SOAEs) hidden in the background of global OAEs signals. However if a coarse frequency resolution is used, it may not allow SOAEs to be detected because the value of the temporal constant is too small. In summary, using the Husimi transform and spectral kurtosis it is possible to distinguish OAE signals, and SOAEs can also be classified based on their kurtosis value.

A high positive kurtosis from evoked OAEs may be interpreted as an indicator of the level of noise in the cochlea. Similarly, a negative kurtosis might indicate the presence of an SOAE. On this basis, it might be possible to compare the kurtosis of normal subjects with kurtosis calculated from subjects with hearing impairments. Such a comparison is the subject of a study.

\section{Appendix}

The Wigner transform plays a crucial role in time series analysis. Let us denote by $Y(\tau)$ the otoacoustic signal registered in time. Then the Wigner transform of the signal can be given as: 


$$
W(t, \omega)=\int_{-\infty}^{+\infty} Y^{*}(t-\tau) Y(t+\tau) e^{-2 \imath \omega \tau} d \tau,
$$

where $\omega$ is the angular frequency of the signal.

It is known that the Wigner transform can yield negative values and generate interference terms if the otoacoustic signal is composed of multiple frequencies. Therefore the Wigner transform should be smoothed in the time and frequency domains using the same Gaussian function. Let us denote by $\sigma t$ and $\sigma \omega$ the time width and the frequency width of the smoothing function and introduce the constant $\kappa$ defined as

$$
\kappa=\frac{1}{2 \sigma_{t}^{2}} .
$$

It is known [21] that the smoothed transform is positive and may represent the probability only when $\sigma t$ and $\sigma \omega$ satisfy the uncertainty condition:

$$
\sigma_{t} \sigma_{\omega}=\frac{1}{2}
$$

The frequency width and the time width determine the time resolution and frequency resolution of time-frequency plots. After smoothing, the Wigner transform becomes the Husimi transform [21].

The Husimi function of the otoacoustic signal $H(t, \omega)$ being used here as a measure of probability is defined as [21]:

$$
H(t, f)=\frac{1}{2 \pi} \sqrt{\frac{\kappa}{\pi}}\left|\int_{-\infty}^{+\infty} e^{-\kappa(\tau-t)^{2} / 2} e^{-2 \pi \imath f \tau} Y(\tau) d \tau\right|^{2} .
$$

The Husimi function represents the probability distribution function on the instantaneous time-frequency plane. It is the probability of having a signal of instantaneous frequency $f$ at time $t$. Thus $H(t, f)$ is the probability distribution function. However, the uncertainty condition means that the spectral resolution of time-frequency diagrams is inversely proportional to the time resolution.
We can define the conditional probability $P(t \mid f)$ of having the emission signal at time $t$ when we know its instantaneous frequency is $f$ :

$$
P(t \mid f)=\frac{H(t, f)}{\sum_{l=1}^{n} H\left(t_{l}, f\right)},
$$

where the sum in the denominator can be denoted as $P(f)$ and is the probability of having the instantaneous frequency of the signal equal to $f$.

This conditional probability is used here as the weight function to calculate the statistical moments. We can then introduce the second definition of kurtosis as a function of frequency, or in other words the spectral kurtosis of the otoacoustic signal:

$$
K(f)=-3+\frac{\sum_{l=1}^{n} P\left(t_{l} \mid f\right)\left(t_{l}-T_{m}\right)^{4}}{\left(\sum_{l=1}^{n} P\left(t_{l} \mid f\right)\left(t_{l}-T_{m}\right)^{2}\right)^{2}},
$$

where $T_{m}(f)$ refers to the mean latency of frequency $f$.

The expression in the denominator represents the fourth power of the spread of latency or the second-order temporal moment of the Husimi distribution [9]. Therefore absolute changes in latencies or in its spread must affect the kurtosis.

The spectral kurtosis $K(f)$ is equal to zero when the probability distribution function is the normal Gaussian distribution or equal to -1.5 when the signal is sinusoidal in time.

\section{Acknowledgments}

We are grateful to W. Wiktor Jedrzejczak for comments on an earlier version of the manuscript.

\section{References:}

1. Kemp DT. Stimulated emission from within the human auditory system. J Acoust Soc Am, 1978; 64: 1386-91.

2. Jedrzejczak WW, Bell A, Skarzynski PH, Kochanek K, Skarzynski H. Time-frequency analysis of linear and nonlinear otoacoustic emissions and removal of a short-latency stimulus artifact. J Acoust Soc Am, 2012; 131(3): 2200-8.

3. Jedrzejczak WW, Blinowska KJ, Kochanek W, Skarzynski H. Synchronized spontaneous otoacoustic emissions analyzed in a time-frequency domain. J Acoust Soc Am, 2008; 124(6): 3720-9.

4. Jedrzejczak WW, Kwaskiewicz K, Blinowska K, Kochanek K, Skarzynski $\mathrm{H}$. Use of matching pursuit algorithm with a dictionary of asymmetric waveforms in the analysis of transient evoked optoacoustic emissions. J Acoust Soc Am, 2009; 126(6): 3137-46.

5. Kuttig H, Niethammer M, Hurlebaus S, Jacobs L. Model-based analysis of dispersion curves using chirplets. J Acoust Soc Am, 2006; 119(4): 2122-31.

6. Martin W, Flandrin P. Wigner-Ville spectral analysis of nonstationary processes. IEEE Transactions on Acoustics Speech and Signal Processing, 1985; 33(6): 1461-70.
7. Tognola G, Grandori F, Ravazzani P. Time-frequency distributions of click evoked otoacoustic emissions. Hear Res, 1997;106: $112-22$.

8. Jedrzejczak WW, Blinowska KJ, Konopka W, Grzanka A, Durka PJ. Identification of otoacoustic emissions components by means of adaptive approximations. J Acoust Soc Am, 2004; 115(5): 2148-58.

9. Keefe DH. Moments of click-evoked emissions in human ears: group delay and spread, instantaneous frequency and bandwidth. J Acoust Soc Am, 2012; 132(5): 3319-50.

10. Wable J, Collet L. Can synchronized optoacoustic emissions really be attributed to SOAEs? Hear Res, 1994; 80: 141-5.

11. Gold T, Hearing II. The physical basis of the action of the cochlea. Proc R Soc Lond B, 1948; 135: 492-8.

12. Fruth F, Julicher F, Lindner B. An active oscillator model describes the statistics of spontaneous otoacoustic emissions. Biophys J, 2014; 107: 815-24.

13. Zweig G. Finding the impedance of the organ of Corti. J Acoust Soc Am, 1991; 89(3): 1229-54. 
14. Shera C. Laser amplification with a twist: travelling-wave propagation and gain functions from throughout the cochlea. J Acoust Soc Am, 2007; 122(5): 3738-58.

15. Sisto R, Moleti A. Modeling otoacoustic emissions by active nonlinear oscillators. J Acoust Soc Am, 1999; 106(4): 1893-906.

16. Sisto R, Moleti A, Lucertini M. Spontaneous otoacoustic emissions and relaxation dynamics of long decay time OAEs in audiologically normal and impaired subjects. J Acoust Soc Am, 2001; 109(2): 638-47.

17. Husimi K. Miscellanea in elementary quantum mechanics, II. Progress of Theoretical Physics, 1953; 9(4): 381-402.

18. Bialek W, Wit HP. Quantum limits to oscillator stability. Theory and experiments on acoustic emissions from the human ear. Physics Letters, 1984; 104A, 3: 173-8.
19. Martin P, Hudspeth AJ, Julicher F. Comparison of a hair bundle's spontaneous oscillation with the response to mechanical stimulus reveals the underlying active process. Proc Nat Acad Sci USA, 2001; 118(25): 14380-5.

20. Antoni J. The spectral kurtosis: a useful tool for characterizing non-stationary signals. Mechanical Systems and Signal Processing, 2006; 20: 282-307.

21. Davidovic MD, Davidovic MD, Vojisavljevic V. Time-frequency analysis of nonstationary optical signals using Husimi type function. Acta Physica Polonica, 2009; 116(4): 675-7.

22. Jedrzejczak WW, Blinowska KJ, Konopka W. Resonant modes in transiently evoked otoacoustic emissions and asymmetries between left and right ear. J Acoust Soc Am, 2006; 119: 2226-31

23. Bergevin C, Fulcher A, Richmond S, Velenovsky D Lee J. Interrelationship between spontaneous and low-level stimulus frequency otoacoustic emissions in humans. Hear Res, 2012; 285: $20-8$. 